\title{
The Unemployment Rate as an Economic Indicator
}

\author{
JEAN M. LOVATI
}

D URING the most recent recession, the unemployment rate rose to its highest level since the depression years of the $1930 \mathrm{~s}$, reaching 8.9 percent in May 1975. The unemployment rate has since declined and stood at 7.9 percent in August of this year. Despite this decline, unemployment is still unacceptably high, with 7.5 million persons reporting that they want to work but have not found jobs. The unemployment picture has been aggravated by increases in the unemployment rate in recent months. Besides contributing to fears that the economic recovery is weakening, such increases intensify pressure for adopting policy measures designed to reduce unemployment.

\section{MEASUREMENT}

The basic source of labor market information is the monthly survey data collected by the Bureau of the Census for the Bureau of Labor Statistics. The civilian noninstitutional population is sampled, ${ }^{1}$ with approximately 50,000 randomly selected households surveyed monthly. With a carefully structured set of questions, information is gathered which results in a determination of the labor force status of the civilian population, age 16 and over. The respondents are never asked specifically if they are employed or unemployed, nor are they given the opportunity to decide their own labor force status. For example, for persons replying that they did not work during the survey week, questions are asked to determine whether they had jobs from which they were absent

1The civilian noninstitutional population includes all persons 16 years of age or older who are not members of the Armed Forces, members of penal or mental institutions, sanitariums, or homes for the aged or infirm.

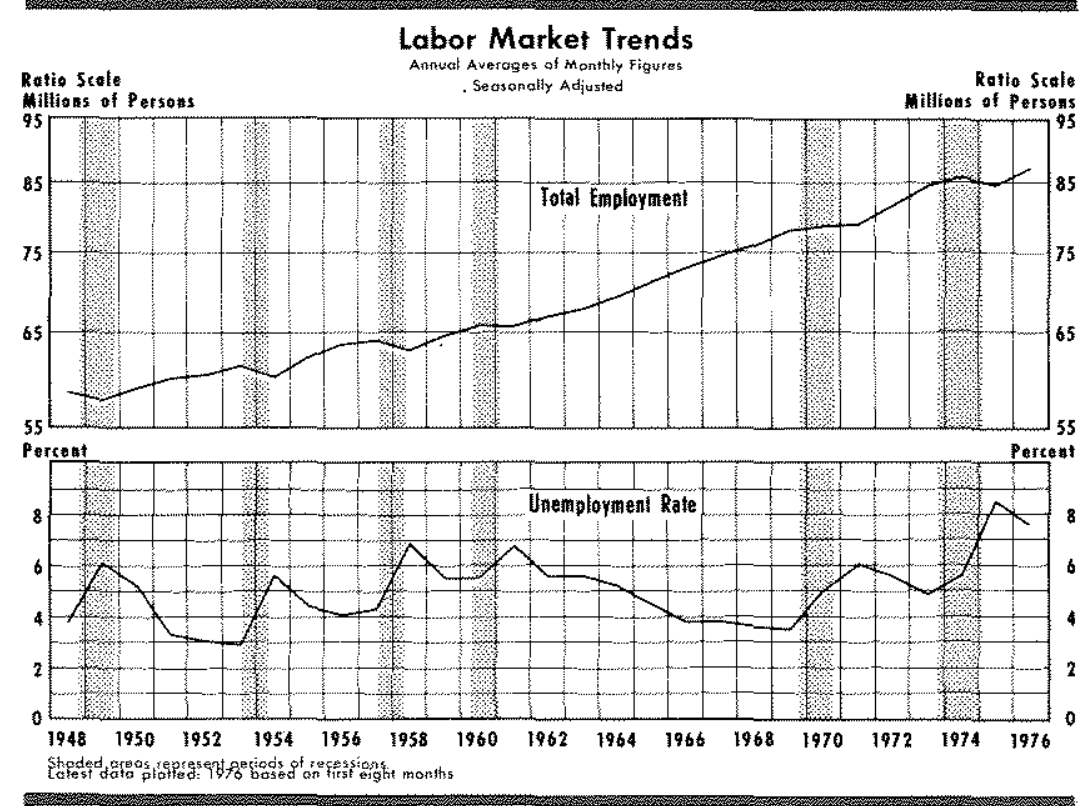

or had no jobs whatsoever. ${ }^{2}$ If the respondents had no jobs, further questions are asked until the sequence of questions which leads to a labor force determination is completed.

Household members are classified as employed if they report doing any work at all for pay or profit during the survey week. This includes part-time and temporary work as well as full-time employment, and incorporates umpaid workers who worked at least 15 hours in a family operated enterprise. Although workers may have been absent from work during the survey week due to illness, vacation, strike, or various personal reasons, they are still considered. employed.

To be classified as unemployed, persons must report being without work during the survey week, being

\footnotetext{
${ }^{2}$ The survey covers the calendar week which includes the 12th of each month, although it is actually conducted in the following week.
} 
currently avallable for work, and having actively sought work at some time in the prior four weeks. Seeking work, in the context of the survey, includes registering at an unemployment office, answering ads, or checking with friends or relatives about job openings. Persons who are waiting to be called back to a job from which they have been laid off or who are waiting to report to a new job within 30 days are considered unemployed, even though they do not seek other work.

The total unemployment figure thus counts more than those who have lost their jobs. It includes persons who have quit their previous jobs to look for other work, new workers looking for their first jobs, and persons looking for jobs after an absence from the labor force. The unemployment rate expresses the number of persons classified as unemployed as a percentage of the civilian labor force.

Household members who are not employed and are not seeking employment are classified as "not in the labor force." Persons in this category are neither employed nor unemployed. Some persons in this category do not participate in the labor force because they are retired, attending school, or engaged in home responsibilities. Others are financially independent, or simply prefer leisure. Still others report

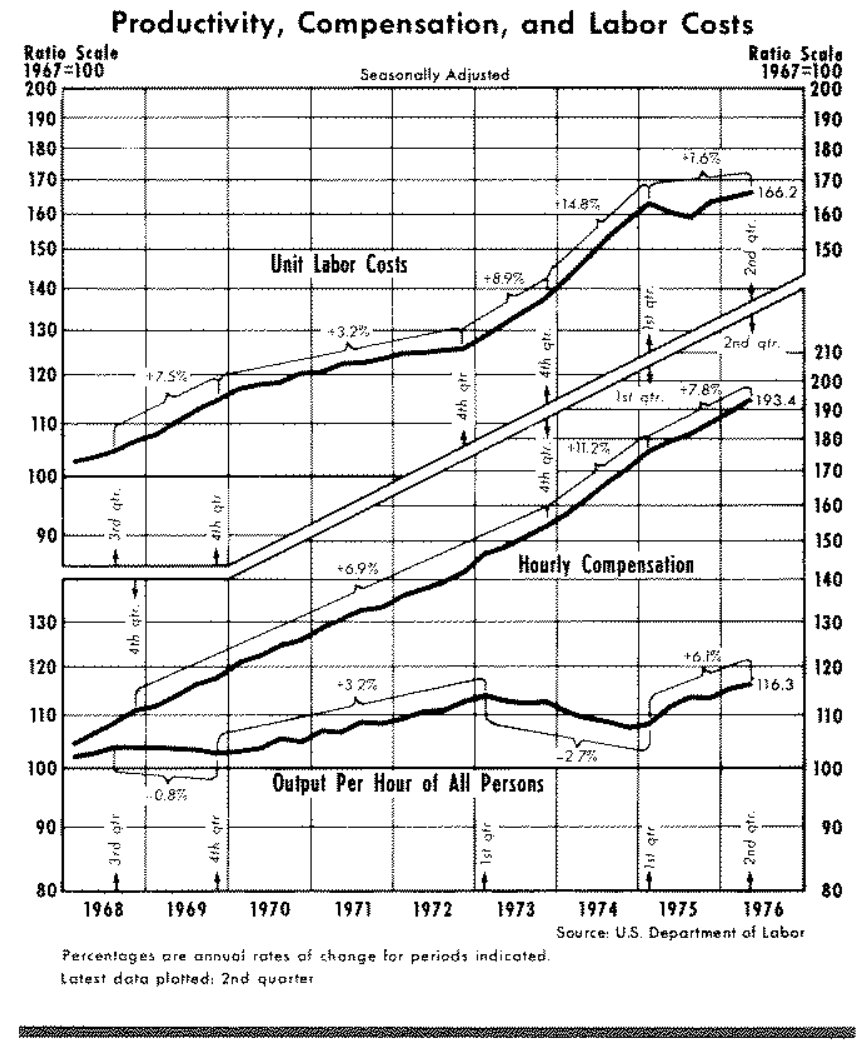

that they do not look for work because they believe that no jobs are available for persons with their experience or training. This group is often referred to as "discouraged workers."

Due to the large size of the household sample, labor market estimates derived from it are generally regarded as reliable in a statistical sense. The data are subject to some degree of sampling error, however, and this must be taken into account when analyzing changes in the data. For the overall unemployment rate, the error is relatively small. To be deemed a significant change, the national unemployment rate would have to move 0.2 percentage point or more on a monthly basis. There is a relatively high probability that movements in the unemployment rate which are smaller than 0.2 percentage point are due to sampling variability, instead of changes in the unemployment situation. Unemployment rates for component groups, because they are based on smaller samples, are subject to larger errors. For example, the statistically significant error on month-to-month movements in the teenage unemployment rate is about 0.9 percentage point, and in the black unemployment rate about 0.8 percentage point $^{3}$

\section{NNTEPPRETATION}

The unemployment statistics represent an attempt to estimate the number of persons who want, but cannot find, work. The data are most often used as measures of labor force utilization and as indicators of general economic activity. These uses seem reasonable (although subject to some limitations) since unemployment, in principle, means human resources are idled and productive opportunities are foregone.

Others use the data as measures of hardship experienced by the unemployed. Hardship resulting from unemployment is influenced by a number of other factors such as the amount of savings, eligibility for unemployment compensation, food stamps, other welfare programs, the number of household members employed, and the extent of payments from former employers or union funds. Because of the growing importance of these other factors, the unemployment rate tends to overestimate the extent of economic hardship suffered relative to periods in the past..$^{\ddagger}$

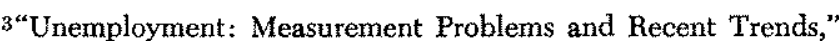
U.S. Department of Labor, Bureau of Labor Statistics, Report 445,1975 .

4The umemployment rate for household heads is often used as a more meaningftul measure of hardship than the total unemployment rate, but this rate is also subject to imitations.
} 


\section{Unemployment Rates*}

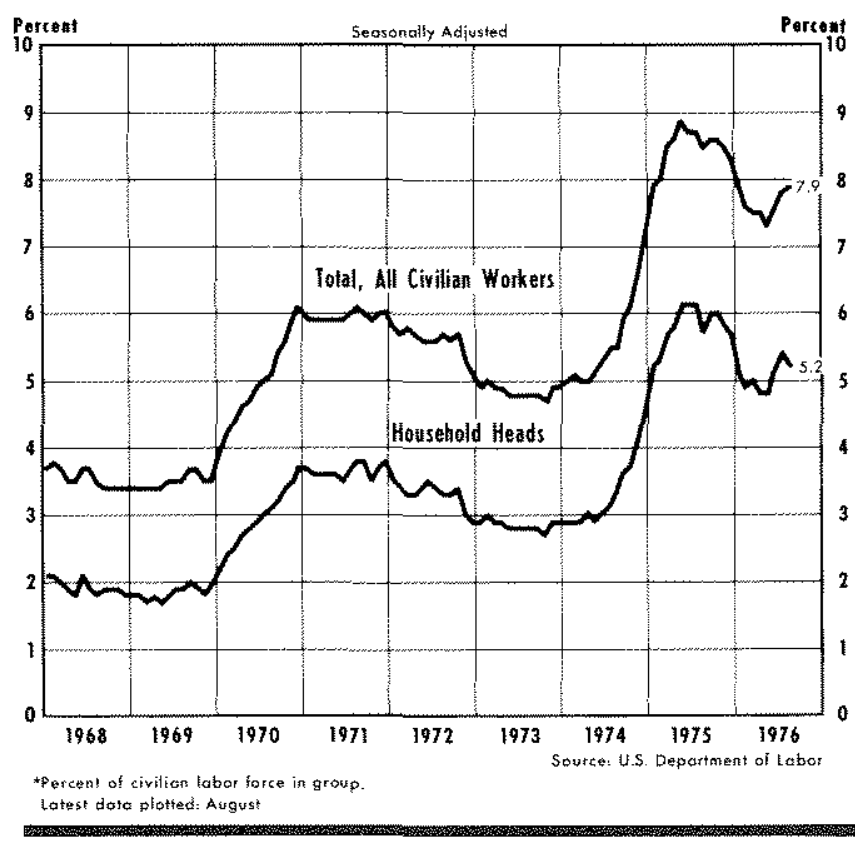

On the other hand, the unemployment statistics might understate the number of persons without work. Because of the current definition of unemployment, discouraged workers - those who forsake job search because they feel no jobs are available for them - are excluded from the official unemployment statistics.

Data collected in recent years indicate that discouraged workers are primarily youths, women, and blacks. If discouraged workers were added to the seasonally adjusted unemployment rate for 1975, the adjustment would add an average of 1.2 percentage points to the total rate. This merely exemplifies the depressed labor market conditions in 1975. In both the years 1973 and 1974, discouraged workers would have added 0.8 percentage point to the total rate had they been included. Of course, the adjustment in the jobless rate for adult men would be relatively small, but would be greater on the already high rates for women, youths, and blacks. In 1975, the addition of discouraged workers would have increased the unemployment rate for Negro and other races an average of 3 percentage points.

One very important difficulty encountered with the unemployment statistics is that questions concerning wages are not part of the survey. Persons reporting that they believe no jobs are available are not asked at what wage jobs appear to be unavailable. Thus no information is gathered on the extent to which unemployment results from an asking wage which is too high. This situation can result from both a generally depressed state of economic activity which has not convinced unemployed workers of the general decrease in their value as factors of production, and artificial restrictions which prevent the asking wage from falling to a level commensurate with productive ability. Only the former case is amenable to the traditional tools of monetary and fiscal policy.

Growth in aggregate demand will not aid those whose unemployment results from labor market imperfections. For example, Government mandated wage restrictions, such as the minimum wage, prevent employers and workers from coming together to bargain for a mutually acceptable wage. Workers, especially teenagers, often are willing to work at wages below the legal minimum but are prevented from doing so. As a result, unemployment in this group rises. Similarly, unions negotiate wage contracts for all employees through collective bargaining and typically set floors on wage offers. If some workers consequently are laid off, they may be willing to work at wage rates below union floors rather than lose their jobs, but find they cannot do so. One alternative is to seek other work, usually at a lower wage.

It should be noted that some degree of unemployment always prevails as workers change jobs to pursue better job opportunities. This type of unemployment is typically short term, usually lasting five weeks or less. Changes in labor supply and demand conditions necessitate changes in employment and wages. As workers become informed of better job possibilities, they make changes across jobs. The unemployment resulting from movements of this sort, called frictional unemployment, is expected in a changing economic environment and thes is not of primary concem for national economic stabilization purposes. ${ }^{5}$

\section{USE OF EMPLOMMENT STATISTICS}

Despite the popularity of the unemployment statistics, their use alone does not provide a complete view of the labor market situation. Use of unemployment figures should be complemented by at least employment data. ${ }^{\circ}$ Too of ten, unemployment statistics signal different labor market actions when viewed alone and when viewed in conjunction with employment figures. This is usually due to movements between

\footnotetext{
\#For a discussion of the different types of unemployment, see Roger W. Spencer, "The National Plans to Curb Unemployment and Inflation," this Retiew (April 1973), pp. 2-13.

SSinilarly, in analyzing the economic state of the nation, the unemployment situation should be reviewed in conjunction with other measures of economic performance, such as industrial production or gross national product.
} 
Table

\section{A COMPARISON OF SELECTED LABOR MARKET MEASURES}

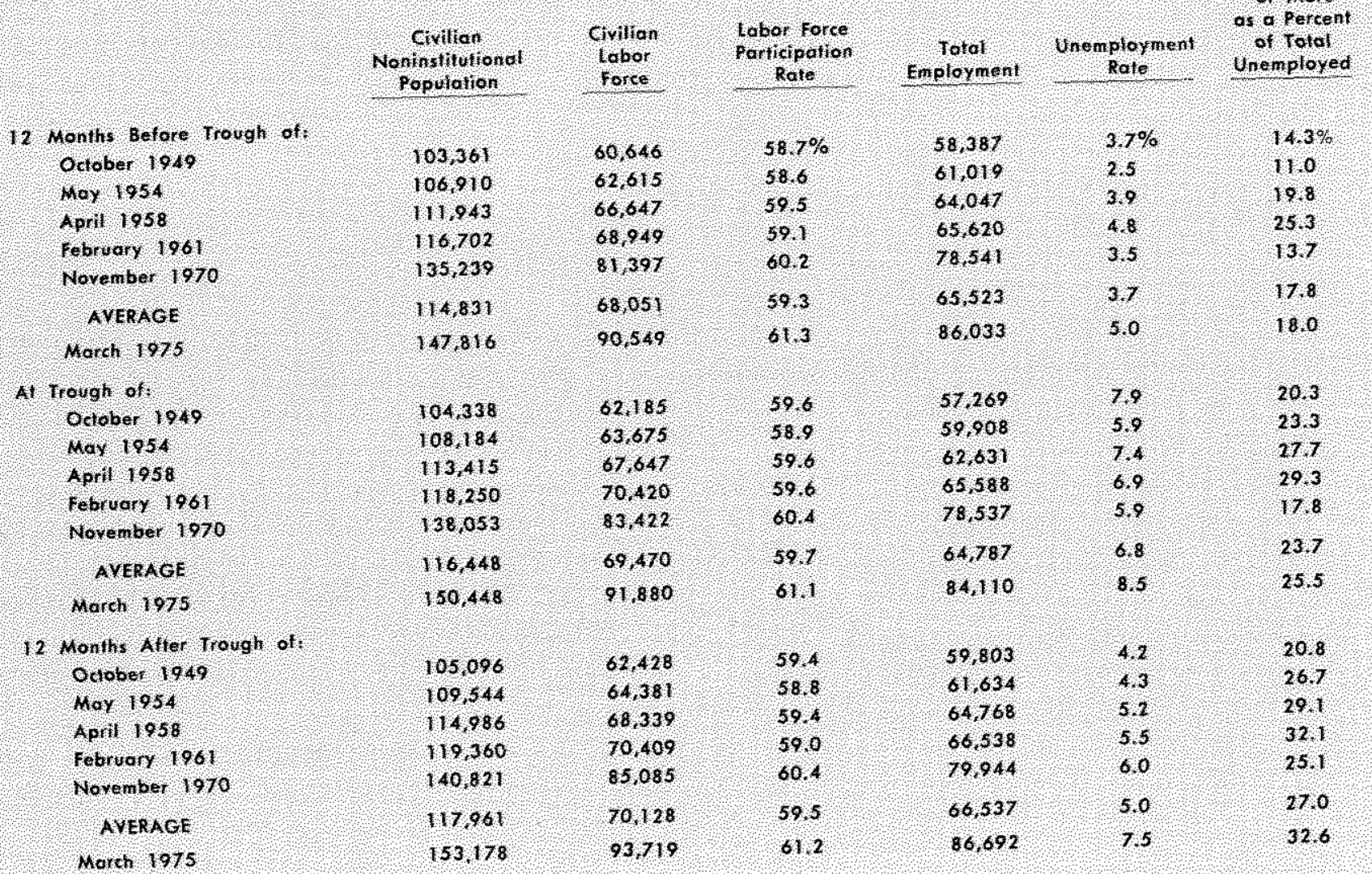

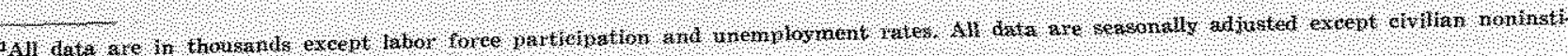
tut ona 1 jowatat on

\begin{tabular}{|c|c|c|c|c|c|c|}
\hline & $\begin{array}{l}\text { chonge roon } \\
\text { anilhon } \\
\text { lobor force }\end{array}$ & $\begin{array}{l}\text { Nonths } \\
\text { Enplose }\end{array}$ & $\begin{array}{l}\text { ogh lo Troogh } \\
\text { Unenoploynent } \\
\text { Rale }\end{array}$ & $\begin{array}{l}\text { Change From } \\
\text { Cevilion } \\
\text { Lebor force }\end{array}$ & $\begin{array}{l}\text { sh } 1012 \text { Mon } \\
\text { Enployment }\end{array}$ & $\begin{array}{l}\text { Aller Trough } \\
\text { Unemploymen }\end{array}$ \\
\hline & $2.54 \%$ & $-191 \%$ & $42 \%$ & $0,39 \%$ & $442 \%$ & $3,7 \%$ \\
\hline October 1949 & 9,60 & $\$ 1,82$ & 3,4 & $1 / 0$ & 2,88 & 116 \\
\hline May 1954 & 1,50 & $s_{2.21}$ & 3.5 & 102 & 341 & 22 \\
\hline Apri 1950 , & 2,3 & $t_{0,05}$ & 21 & 0,02 & 1,45 & $1+4$ \\
\hline February 1969 & 2,49 & - 0.01 & 2,4 & 198 & 1,79 & 01 \\
\hline loventer 1970 & 2,08 & 11,12 & 31 & 0,94 & 270 & -18 \\
\hline$\triangle Y B B A G$ & 14 & 2,23 & 3.5 & 199 & 306 & 10 \\
\hline Mord 1975 & 144 & & & & & . \\
\hline
\end{tabular}

the categories of "unemployed" and "not in the labor force." A more complete representation and different explanation of the labor market situation may restult when movements in employment are also considered.

Employment figures have several advantages over the unemployment figures. Employment is a more solid and objective concept than is unemployment. With few exceptions, persons working during the survey week are considered employed. Identification of employment is relatively straightforward and thus easier to measure than unemployment, where classification depends on more provisos and is subject to more uncertainties (such as in determining whether a person is actively seeking work or is currently avail able for work.${ }^{7}$ Also, employment figures are more closely tied to output measures than are unemployment data. Decisions to look for work, for example,

7Employment statistics are not without definitional problems, however. Questions concerning the status of 


\section{Total Employment}

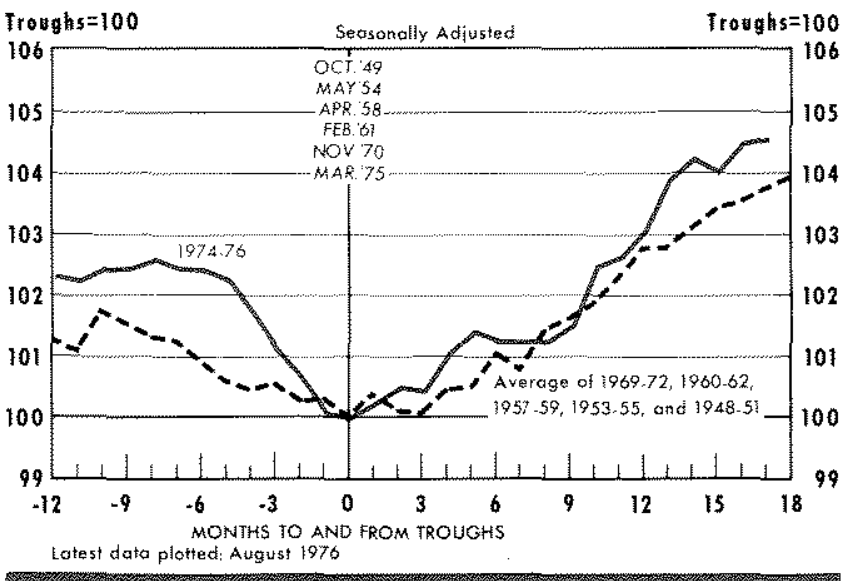

often are based on personal factors, unrelated to economic considerations.

\section{CICLICAL BEHAVIOR}

Since it takes time for labor market actions to be reflected in the unemployment rate, movements in this rate generally trail economic activity. As the level of economic activity falls, for example, it is usually more feasible for employers to initially adjust work schedules of existing workers than it is to discharge workers employed for some time. Although actions such as these signal the decline in economic activity, they are not picked up by the unemployment data until the workers are laid off. In a recovery, employers are likely to increase hours worked of current employees rather than begin hiring procedures. Thus, the unemployment rate tends to understate the extent of a decline in economic activity at the start of the decline and the extent of the recovery later on. In past recessions, the unemployment rate typically has peaked from one to four months after the trough of the general business cycle.

\section{Emploument and Unemploument}

The labor market response to the most recent downturn differs substantially from the behavior in other postwar recession/recovery periods. ${ }^{8}$ Total employment in this recovery has already reached pre-recession levels. Employment has been increasing since March 1975, after a 5.2 percent annual rate of decline in the previous five months. This decline represents a marked change from the average of employ-

sThe most recent recession is compared with the five postwar recessions which reached their troughs in November 1970 , February 1961, April 1958, May 1954, and October 1949 . Recessions are identified by their trough months in this article.

\section{Unemployment Rate}

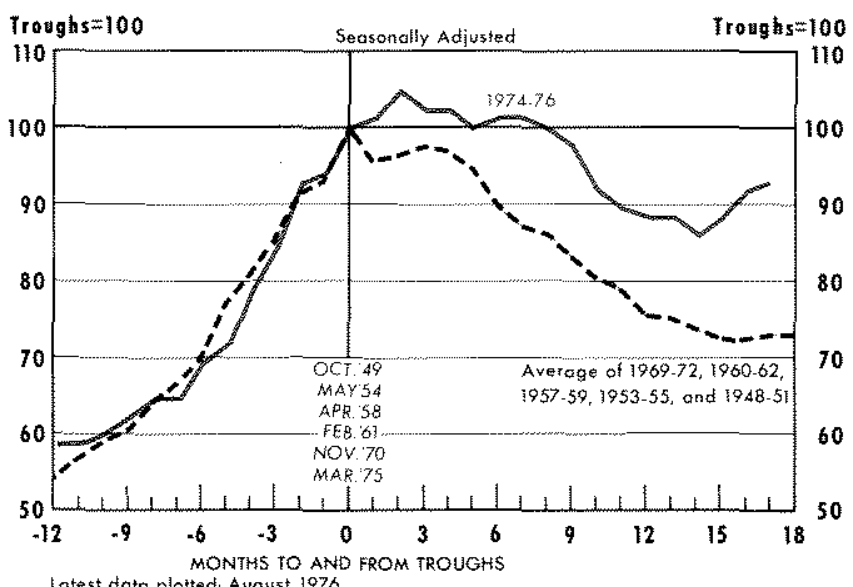

Oatest dato piofted August 1970

ment movements of the previous five recessions. In these recessions, employment declined at a slower rate, averaging a 1.1 percent drop in the 12 months before the troughs. Employment in the 1970 recession remained fairly constant throughout most of the economic decline, only varying by about 350,000 workers in the 12 months preceding the trough. The 1961 recession also did not register great declines in employment. Between June 1960 and February 1961, total employment declined at a 1.3 percent annual rate (see Table I, p. 5, for comparison).

Despite the steep decline, employment in the most current period recovered faster than the average of employment in other recession/recovery periods. Total employment increased at a 3.1 percent rate over the year since the 1975 trough, compared to a 2.7 percent average rate of increase for other recovery periods. This difference has been made even more apparent since March of this year. Between March and August 1976, total employment rose at an annual rate of 3.6 percent, widening the gap between employ w ment movements in the most current and previous recoveries (see accompanying chart). By August 1976, employment reached 88 million workers, an increase of four million workers in this recovery period.

While employment growth has been strong in this recovery period, the unemployment rate has declined only slowly. In August of this year, the unemployment rate was only 0.6 percentage point below the rate at the trough. Compared to the average of previous recoveries, the unemployment rate remains remarkably high. Twelve months after the five prior troughs in economic activity, the unemployment rate had dropped an average of 1.8 percentage points, com- 
Iotal Civilian Labor Force as a Percent of Civilian Non-Institutional Population $(16-64)^{*}$

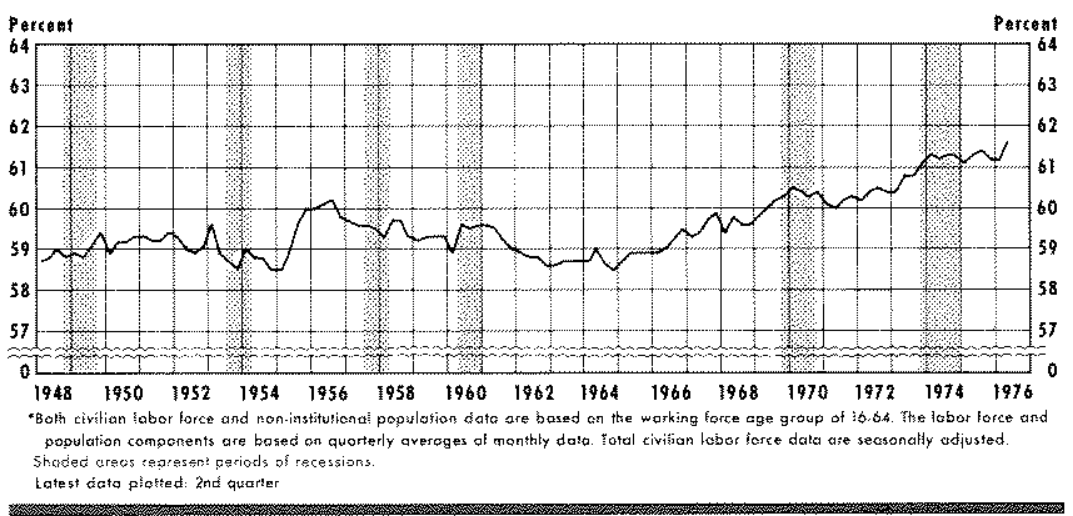

spectively. For the same period after the 1961 trough, labor force growth declined by 0.1 percent.

Several factors have influenced this labor force growth. A primary consideration is the increase in labor force participation. ${ }^{10}$ The participation rate in August reached a high of 61.9 percent of the population. The labor force participation rate of adult women is particularly noteworthy. As inflation erodes real family income, other household members, particularly women, are likely to be drawn into the labor force. This movement has compounded the effect of the trend for increased participation of women. By August 1976, the participation rate of women reached 47.4 percent. This is an increase of 4.1 percentage points since 1970 and 9.8 percentage points since 1960. As of August of this year, adult women comprised 36.3 percent of the labor force. Another group accounting for a larger proportion of the labor force than heretofore is teenagers. The labor force participation rate for workers in the age group 16-19 averaged 54.5 percent during 1974 and 1975 , the highest in recent history. In August of this year, the participation rate for teenagers reached 55.4 percent. The shifting composition of the labor force toward women and youths and the higher unemployment rates gen-

IoLabor force participation rates measure the percentage of persons in a given population, however defined, that are in the labor force. force averaged 0.9 percent. In particular, in the twelve months following the April 1958 trough, the civilian labor force grew at half that rate, and during the same period after the 1961 recession, the labor force declined by 0.02 percent.

In recent months, the differences in labor force growth have become increasingly more evident. From April to August 1976 , the civilian labor force grew at a 3.4 percent annual rate. Labor force growth has averaged a 2.8 percent annual rate over the prior seventeen months. Seventeen months after the low points of the 1958 and 1949 recessions, the civilian labor force had grown by annual rates of 0.9 and 0.4 percent, re

9The exception is the recovery from the Novem" ber 1970 recession in which the civilian labor force grew at about a two percent rate in the twelve months following the trough.

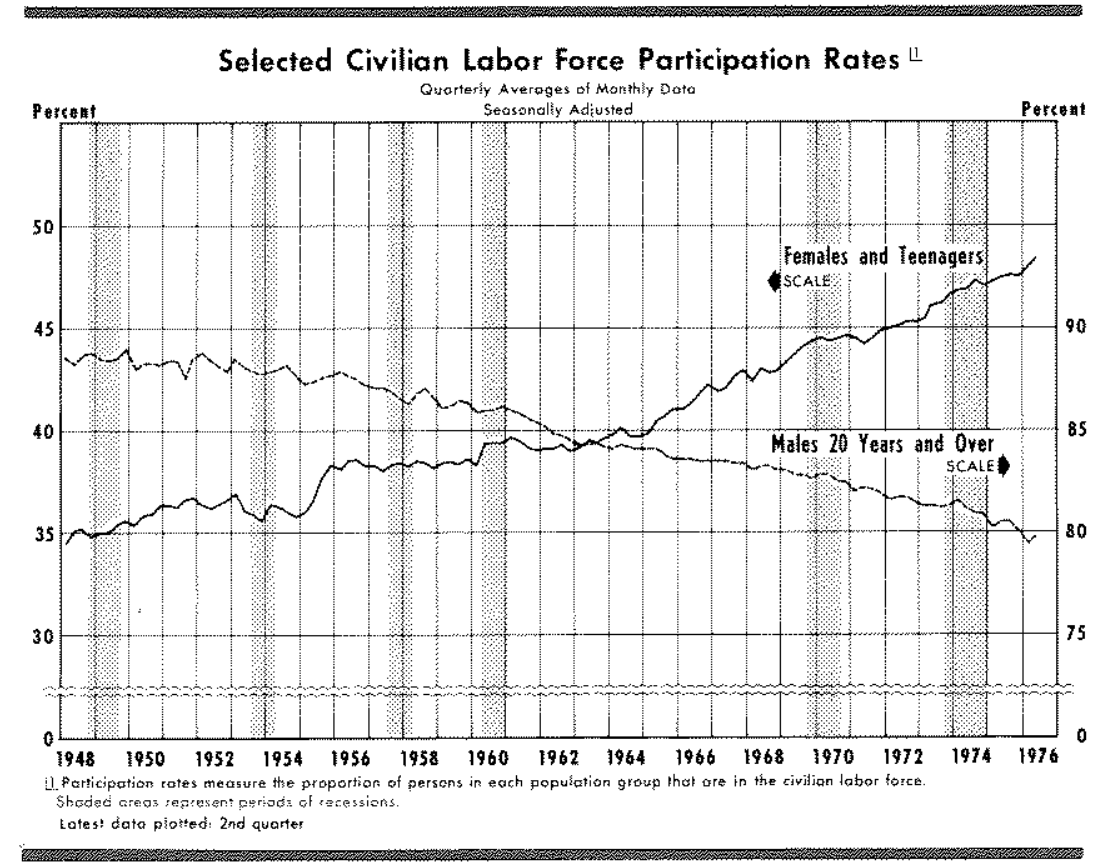


erally experienced by these groups tend to raise the average level of the overall unemployment rate (see chart entitled "Selected Civilian Labor Force Participation Rates").

\section{Durntion of Unemployment}

The behavior of the unemployment rate in this recovery may also be related to factors which tend to lengthen the duration of the unemployment period. During the most recent recovery, the percentage of the unemployed without work for 15 weeks or more was larger than in previous recovery periods. At the trough of the 1975 recession, 26 percent of the unemployed were jobless for 15 weeks or more, compared to 18 percent at the trough of the 1970 recession and 20 percent of the unemployed at the 1949 trough. Nine months after the trough of the most recent recession, 22 percent of the unemployed were jobless for 27 weeks or more, while 11 percent of the unemployed were still jobless after 27 weeks during the 1970 recession. Nine months after the troughs of the 1954 and 1949 recessions, 15 and 11 percent, respectively, of the unemployed still had been without work for 27 weeks or more.

The duration of unemployment depends in part on the cost of remaining unemployed which, in turn, is influenced by the current system of unemployment compensation as well as other benefit programs. By significantly reducing the cost of remaining unemployed, unemployment compensation tends to increase the time devoted to searching for a job and thus lengthens the average duration of unemployment. ${ }^{11}$

In 1975 Congress broadened the scope of eligibility for unemployment insurance benefits and provided additional benefits of up to 13 weeks a year for covered unemployed workers who have exhausted their regular benefits. Since workers covered by unemployment insurance have been eligible for 26 weeks of benefits per year and some states provide an additional 13 or more weeks, this extension by Congress enabled many unemployed workers to receive benefits for one full year or more.

Expansion of insurance payments, coupled with supplementary unemployment benefits and other sources of aid such as food stamps, tend to reduce in-

\footnotetext{
11Longer search time, however, is not necessarily undesirable. Accepting the first job offer reduces the probability of geting the highest-paying job and lowers one's wealth compared to what it would have been had one taken longer to find other jobs, Thus, taking more time to search for a job may "pay of" by resulting in higher lifetime earnings.
}

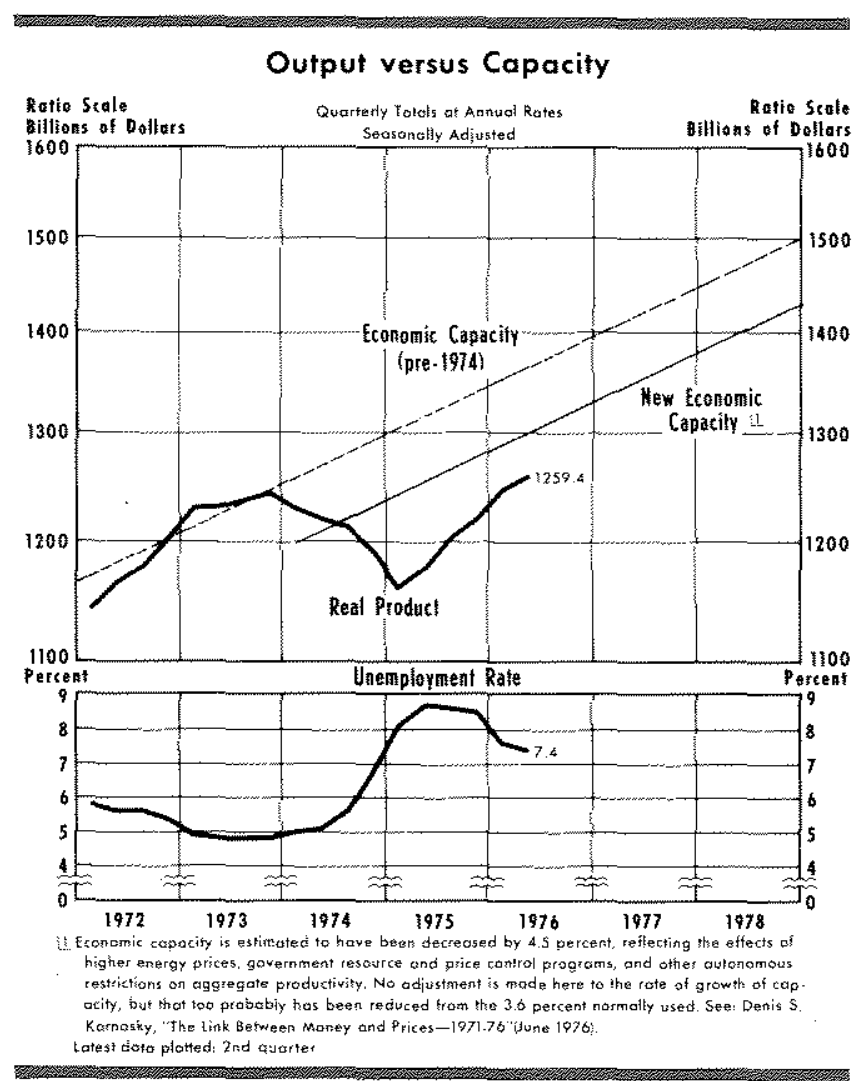

centives to look for work. ${ }^{12}$ Jobs are available even during periods of highest unemployment; that is, job vacancies do not completely dry up, but wages tend to be unacceptably low in view of alternative prospects. Workers in effect are discouraged from taking lower paying or less desirable jobs when their current spendable income, comprised of tax-free unemployment insurance payments, is not very different from their income after taxes derived from work experience. As a result, unemployment and the unemployment rate tend to decrease more slowly.

\section{OUTIOK}

Although the unemployment rate has increased in recent months, its rise is apt to convey a misleading picture of the state of the labor market and the underlying strength of the current recovery. Other factors reflect a more encouraging economic picture. Industrial production, for example, rose at an annual rate of 7.6 percent since January of this year. Real gross national product increased at a 6.7 percent annual rate in the first two quarters of 1976.

While the labor force has been growing at an exceptional rate, so has employment. Since Jamuary 1976,

12See Martin Feldstein, "The Economics of the New Unemployment," The Public Interest (Fall 1973). 
total employment rose by 1.8 million workers, a 3.6 percent annual rate of increase. In the past year, employment rose by 3.2 percent. Thus, output growth has been such that jobs are being provided not only to those who became unemployed during the recession, but also to the growing numbers entering the labor force.

Moreover, more people have been voluntarily seeking other jobs in the past year than was previously the case. Approximately 13 percent of those unemployed in August voluntarily left their jobs to seek better opportunities, compared to 10 percent of the unemployed eleven months before. Typically, this upward trend signals increased confidence on the part of the job leavers that they will be able to find better jobs.

While job leavers are an increasing share of the unemployed, job losers and new entrants/reentrants into the labor force have been a decreasing proportion of the jobless. The number of job losers among the unemployed declined from 58.5 percent in June 1975 to 49.3 percent in August 1976. New entrants and reentrants together represented 38 percent of the unemployed in August, down two percentage points since January. This downward trend suggests that the increasing rates of participation, and thus the strong labor force growth, may be slowing. If this is the case, and if output growth continues at generally expected rates, unemployment is likely to decline.

\section{SUMMARY}

With over seven million persons unemployed, the nation is confronted with one of the highest unemployment rates in recent history. Moreover, when compared to the average of previous postwar recoveries, the unemployment rate has made little progress toward decline.

One reason for this failing is that the labor force has grown at a much faster rate in this recovery than in previous ones. New entrants and reentrants have shifted the composition of the labor force toward more women and youths, groups which have higher unemployment rates. In addition, the relatively high number of unemployed may be maintained due to incentives for prolonged job search provided by an expanded system of unemployment insurance compensation.

Despite the high rate of unemployment, relief may be in the offing. Growth in employment has been strong. Confidence in the economy to continue providing jobs is evident. If increases in labor force participation rates decelerate, the expanding economy should be able to integrate the currently unemployed into desired jobs.

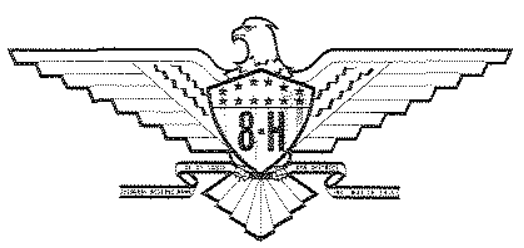

